\title{
Switched reluctance drives for electric vehicle applications
}

\author{
P.Andrada, M.Torrent, B.Blanqué, J.I.Perat \\ Department of Electrical Engineering \\ E.U.P.V.G., Technical University of Catalonia (UPC) \\ Victor Balaguer s/n, 08800 Vilanova i la Geltrú, Barcelona (Spain) \\ phone:+34 93 8967732, fax:+34 93 8967700, e-mail: andrada.@ee.upc.es
}

\begin{abstract}
Electric vehicles are the only alternative for a clean, efficient and environmentally friendly urban transport system. With the increasing interest in electric vehicles, a great effort is required in order to develop electric drives for electric vehicle propulsion. This paper first tries to explain why the switched reluctance drive is a strong candidate for electric vehicle applications. It then gives switched reluctance drive design guidelines for battery or fuel cell operated electric vehicles. Finally, it presents the design and simulation of a switched reluctance motor power train.
\end{abstract}

\section{Key words}

Electric vehicle, electric drives, power drive train, switched reluctance motor.

\section{Introduction}

Environmental and economic considerations are the major reasons for the development of electric vehicles. Exhaust emissions from the internal combustion engine are the main source of urban pollution and one of the most important causes of the greenhouse effect. The pollution problem only gets worse with increasing numbers of automobiles. There is also an economic factor arising from the poor energy conversion efficiency of the internal combustion engine. When efficiency is evaluated on the basis of conversion from crude oil to road load at the wheels, the numbers for electric vehicles are not significantly higher than for internal combustion engine vehicles (19.64\% for electric vehicles, $10.26 \%$ for internal combustion engine vehicles). Moreover, efficient power generation at electric plants together with very high motor and controller efficiency and advancements in power source technology within the vehicle, battery or fuel cell, mean that electric vehicles offer huge possibilities for improving overall efficiency.

This paper shows the capabilities of switched reluctance motors as a power train for battery or fuel cell operated electric vehicles and gives design guidelines. The paper is divided into six sections. Section 2 summarizes basic electric vehicle dynamics and gives drive specifications. Different alternatives to electric drives for electric vehicles are presented in Section 3. Section 4 revises the relationship between switched reluctance motor drives and electric traction, and gives design guidelines for sizing switched reluctance motors for electric vehicles. A design proposal for a switched reluctance motor and the simulation of its specified car performances is presented in Section 5, and the conclusions in Section 6.

\section{Basic electric vehicle dynamics and drive specifications}

The motive force at the wheels or road load, $F$, consists of gravitational force, rolling resistance of the tyres, aerodinamic drag force, and acceleration force, that is [1].

$$
F=\left(c_{0}+\sin \beta\right) m g+0,5 \rho C_{D} S\left(v+v_{0}\right)^{2}+k_{m} m \frac{d v}{d t}
$$

where $c_{0}$ is the tyre rolling resistance, $\beta$ is the angle with respect to the horizontal, $m$ is the gross mass of the vehicle, $g$ is the acceleration due to gravity, $\rho$ is the air density, $C_{D}$ is the aerodynamic drag coefficient, $S$ is the vehicle frontal area, $v$ is the vehicle speed, $v_{0}$ is the head-wind speed and $k_{m}$ is the rotational inertia coefficient. In this paper the parameters affecting drive performance are fixed at the following values: Gross weight around $1500 \mathrm{~kg}$, cruising speed $120 \mathrm{~km} / \mathrm{h}$, maximum speed $180 \mathrm{~km} / \mathrm{h}$, and a gradability or climbing capability of about $40 \%$. These performance parameters are typical for a subcompact car powered by a 1600 to $1800 \mathrm{~cm}^{3}$ gasoline internal combustion engine. The choice of the power train for these performance parameters is based on the road load to speed envelope derived from equation (1), see Figure 1. Recent studies reveal that operational constraints on vehicles, such as initial acceleration and gradability, can be better meet with a minimum power rating if the power train can be operated mostly in the constant power region [2],[3].

Electric vehicles should be designed and controlled to optimize efficiency and regenerative braking. With the advances in power electronics, high efficiency operation in different road conditions can easily be achieved by electronic means rather than mechanical means and therefore a fixed gear ratio between the propulsion motor and driving wheels is used [4]. The choice of a suitable reduction factor involves aspects such as motor size, 


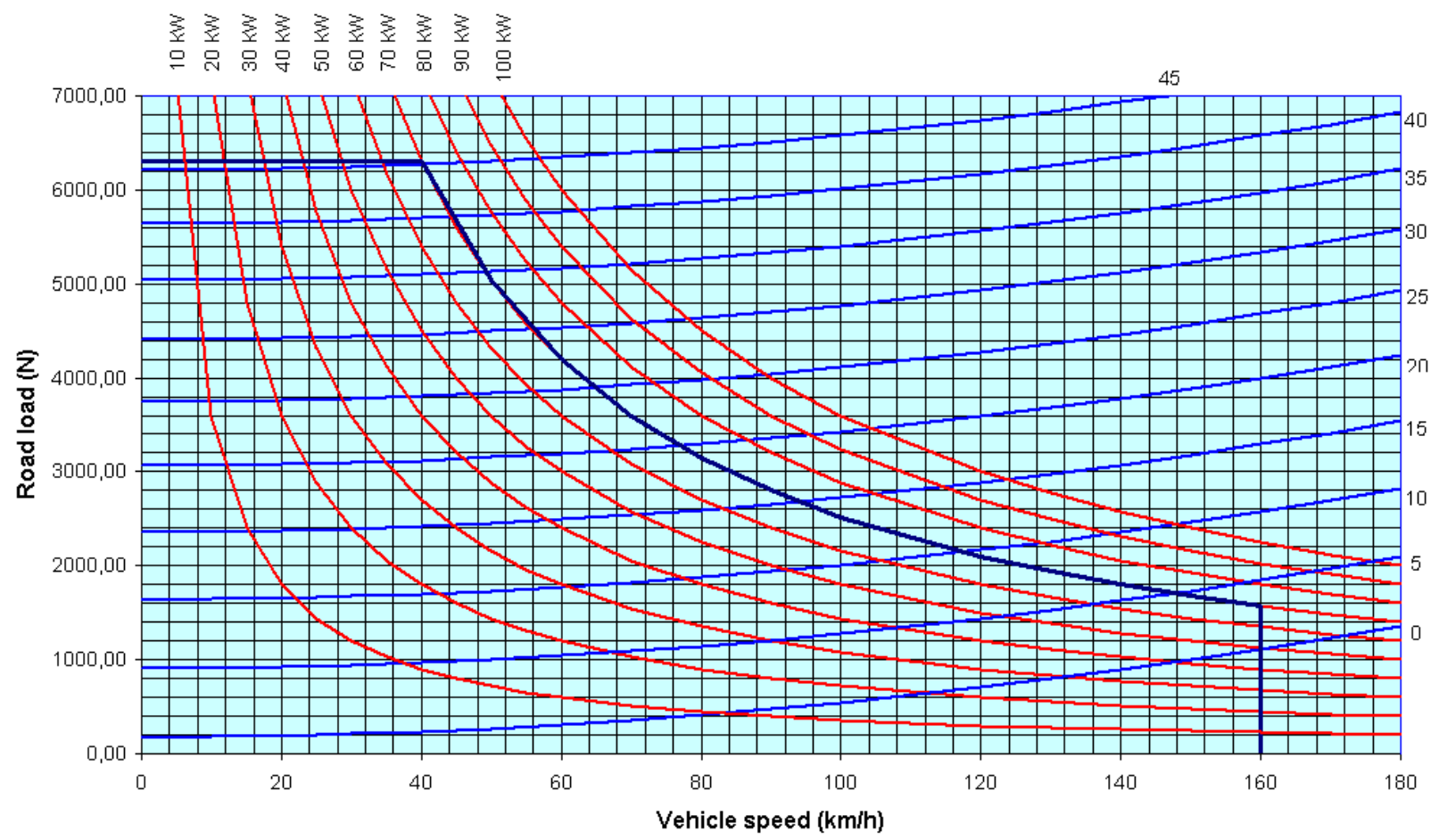

Fig. 1. Road load-speed envelope. In red, lines of equal power (10 to $100 \mathrm{~kW})$; in blue road load vs. speed for different percentage gradabililty ( 0 to $40 \%)$.

size, maximum frequency and power loss, mainly in the iron core but also in the power converter. Appropriate values for a wheel radius of $0.3 \mathrm{~m}$, are between 5 and 12 . Electric propulsion demands an energy source that could be advanced batteries (NiMH or Li-ion) or preferably a fuel cell (PEM) [5],[6]. The voltage at D.C. bus must be higher than $300 \mathrm{~V}$ D.C., but if this voltage is not regulated, rated power and torque must be fulfilled at minimum voltage. Therefore, taking into account the above car performance parameters, the drive specifications should be: Power $75 \mathrm{~kW}$, Maximum torque $220 \mathrm{Nm}$, Base speed $3200 \mathrm{rpm}$, Maximum speed around $12500 \mathrm{rpm}$, Constant power operating range 4 times base speed, and Gear ratio 9. Figure 2 shows the motor shaft torque versus rotor speed profile, and indicates the different operating zones. Additional requirements are four quadrant operation, overload (at least $50 \%$ of maximum torque for $90 \mathrm{~s}$ duration), high efficiency ( $>85 \%$ in almost all operating conditions, and even $>90 \%$ at rated conditions), and low weight.

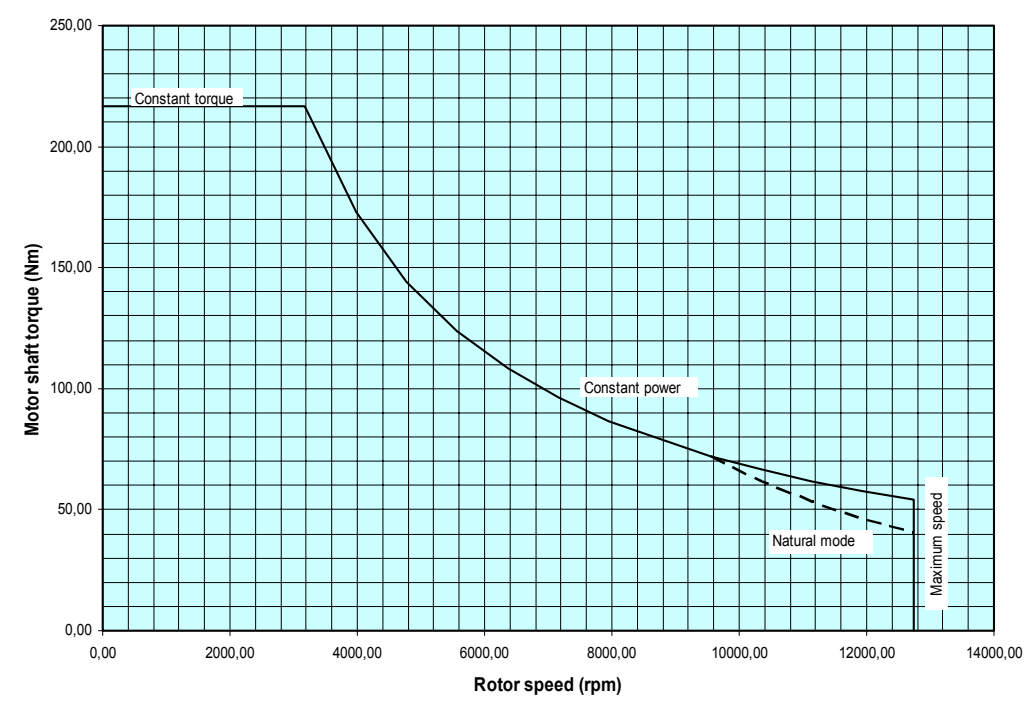

Fig. 2. Motor torque-speed profile 
TABLE I.- Comparison of BDCMD, SPMMD, SRMD and IMD for electric vehicle application

\begin{tabular}{|c|c|c|c|c|c|}
\hline Items & Maximum & BDCMD & SPMMD & SRMD & IMD \\
\hline Power density & 10 & 9 & 10 & 8 & 7 \\
\hline Overload & 10 & 7 & 7 & 8 & 9 \\
\hline Efficiency & 10 & 9 & 10 & 8 & 7 \\
\hline High speed range & 20 & 10 & 16 & 18 & 16 \\
\hline Control & 20 & 15 & 15 & 16 & 16 \\
\hline Noise & 10 & 8 & 8 & 6 & 8 \\
\hline Torque ripple & 10 & 6 & 8 & 5 & 7 \\
\hline Size and weight & 10 & 8 & 9 & 7 & 7 \\
\hline Ruggedness & 20 & 14 & 14 & 17 & 16 \\
\hline Maintenance & 10 & 8 & 8 & 9 & 9 \\
\hline Manufacturability & 20 & 14 & 12 & 18 & 16 \\
\hline Cost & 30 & 20 & 18 & 26 & 28 \\
\hline Total & 180 & 128 & 135 & 146 & 146 \\
\hline
\end{tabular}

\section{Electric drives for electric vehicles}

In selecting an electric drive for electric vehicles, considering single power train, the following items were considered: power density, overload, efficiency, high speed range, control, noise, torque ripple, size and weight, ruggedness, maintenance, manufacturability and cost. Nowadays, several electric drives fulfil requirements in these categories: Brushless D.C. drives (BDCMD), Synchronous permanent magnet motor drives (SPMMD), Switched reluctance motor drives (SRMD), and Induction motor drives (IMD). The choice of the best candidate involves weighting the requirements according to a specific standard of desirability [7]. In this paper, points are awarded for each one of the requirements: maximum points indicate the drive that best meets the requirement. From Table I, the best placed challengers are induction motor drives and switched reluctance motor drives. After recognizing that the two drives have similar merits, we selected a switched reluctance motor because ruggedness (robustness, reliability and fault tolerance capability) and manufacturability (simplicity of laminations. absence of magnets and concentrated windings) are very important qualities for mass production of motor drives for electric vehicles.

\section{Switched reluctance motor drive for electric vehicle}

\section{A. Switched reluctance motor drive and electric traction}

Switched reluctance motor have always been related to electric traction. The first documented switched reluctance motors appeared in the period 1837-1840, and one of their earliest applications (as in Robert Davidson's design) was powering a locomotive on the GlasgowEdinburgh railway. However, the rapid development of D.C. motors in the second half of the 19th century soon eclipsed switched reluctance motors. The appearance of solid state controlled interrupters started to renew interest in switched reluctance motors, but the modern era of switched reluctance motors did not begin until the late $1970 \mathrm{~s}$ thanks to a research project on battery powered electric vehicles carried out by the Universities of Leeds and Nottingham and sponsored by Chloride Technical Ltd. [8],[9]. In recent years several important automobile manufacturers have been developing switched reluctance motors as drive trains for their prototype electric cars [10]-[16].

\section{B. Switched reluctance motor drive, some design guidelines}

\section{Sizing the Switched reluctance motor}

Switched reluctance motor for electric cars need to exploit their advantages to the full while overcoming their disadvantages, mainly torque ripple and acoustic noise. Switched reluctance motors for electric vehicle need a high power density. Therefore, torque per rotor volume values of 40 to $70 \mathrm{kNm} / \mathrm{m}^{3}$ should be applied in the initial sizing stage. This entails high values of magnetic and electric loading. Although a magnetic material with high saturation flux density is selected, magnetic loading cannot increase very much, so electric loading must reach very high values. As a consequence, high current densities (from 16 to $20 \mathrm{~A} / \mathrm{mm}^{2}$ ) should be used, the slot fill factor should be more than $50 \%$ and liquid cooling is mandatory. The airgap should be as small as mechanical tolerances allow.

Electric vehicles need to have an extended constant power range. A reasonable margin is 3 to 4 times base speed a margin within the capabilities of switched reluctance motors.

Suitable selection of the number of phases and poles is very important in order to meet expected motor performance parameters. Different combinations of stator/rotor pole number have been proposed for switched reluctance motors for electric vehicle applications: $6 / 4$, $12 / 8$ and 24/16 for three phase motors, and 8/6 and 16/12 for four phase motors, see Table II. Many factors are involved in the choice: the number of power interrupters, the number of strokes, the inductance ratio, the energy conversion area, the switching frequency, cooling of the coils, and acoustic noise. Options with a multiplicity of one reduce $\mathrm{Hz} / \mathrm{rpm}$ but are clearly noisier, while in options with high multiplicity the disadvantages tend to outweigh the advantages. 
TABLE II.- Stator/rotor pole number combinations

\begin{tabular}{|c|c|c|c|c|c|c|}
\hline $\begin{array}{c}\text { Stator/rotor } \\
\text { pole } \\
\text { number }\end{array}$ & $\begin{array}{c}\text { Number } \\
\text { of } \\
\text { phases }\end{array}$ & Multiplicity & $\begin{array}{c}\text { Number } \\
\text { of poles } \\
\text { per phase }\end{array}$ & $\begin{array}{c}\text { Stroke } \\
\text { angle } \\
\left({ }^{\circ}\right)\end{array}$ & $\begin{array}{c}\text { Number of } \\
\text { strokes per } \\
\text { revolution }\end{array}$ & $\begin{array}{c}\text { Switching } \\
\text { frequency } \\
\text { per rpm } \\
(\mathrm{Hz} / \mathrm{rpm})\end{array}$ \\
\hline $6 / 4$ & 3 & 1 & 2 & 30 & 12 & $1 / 15$ \\
\hline $12 / 8$ & 3 & 2 & 4 & 15 & 24 & $1 / 7,5$ \\
\hline $24 / 16$ & 3 & 4 & 8 & 7,5 & 48 & $1 / 3.75$ \\
\hline $8 / 6$ & 4 & 1 & 2 & 15 & 24 & $1 / 10$ \\
\hline $16 / 12$ & 4 & 2 & 4 & 7,5 & 48 & $1 / 5$ \\
\hline
\end{tabular}

Thin laminations with very high saturation flux density and extremely low iron loss are the best choice but unfortunately the magnetic material closest to meeting these requirements, cobalt iron alloy, is very expensive. The alternative is to use steel laminations with moderate saturation flux density and low iron loss.

\section{Power converter}

Numerous different topologies have been proposed for electrical vehicle applications powered by switched reluctance motors [16]. However, the preferred topology consists of an asymmetrical half-bridge or classic converter, with two solid-state power interrupters and two diodes per phase. Due to the current and voltage levels managed, IGBT's are the best choice for solidstate power interrupters. Specific power modules for this kind of converter have not been commercially available up to now.

\section{Control}

Complex torque control is required for electric car applications [17]. The Control variables are current amplitude and turn-on and turn-off angles. The control algorithm, implemented on a DSP, should continuously adjust current, turn-on angle, turn-off angle and current amplitude to maintain average torque at the required level, decoupled from D.C. voltage variations and speed changes. Bellow base speed, PWM is used, and in order to maintain torque ripple within tolerable limits current profiling must be considered. Above base speed, in the constant power range and field weakening zone, the only control parameters are turn-on and turn-off angles.

\section{Proposed design and simulation.}

In order to meet the specifications in Section 2, following the guidelines in Section 4 a $75 \mathrm{~kW}, 300 \mathrm{~V}$, $12 / 8$ switched reluctance motor prototype was designed, see Figure 3. Table III gives its most important parameters. Figure 4 presents finite element analysis [18] showing flux distribution in aligned and non-aligned positions. Simulink simulation of the drive [19] is shown in Figures 5 and 6.

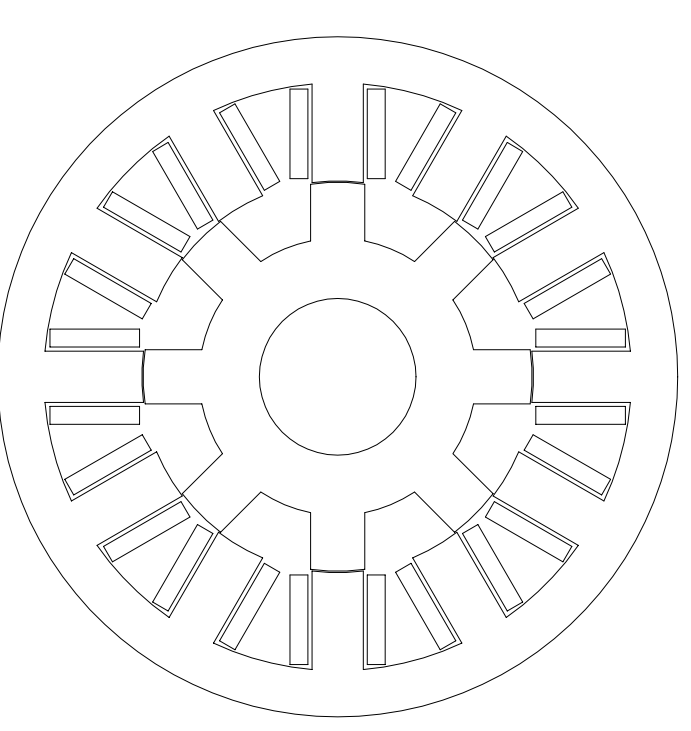

Fig. 3.- 12/8 Switched reluctance prototype

TABLE III.- Main dimensions of the prototype.

\begin{tabular}{|l|c|}
\hline \multicolumn{1}{|c|}{ Parameter } & Value \\
\hline Number of phases & 3 \\
\hline Number of stator poles & 12 \\
\hline Number of rotor poles & 8 \\
\hline Stator outer diameter $(\mathrm{mm})$ & 243 \\
\hline Rotor diameter $(\mathrm{mm})$ & 139 \\
\hline Stack length $(\mathrm{mm})$ & 243 \\
\hline Airgap $(\mathrm{mm})$ & 0.5 \\
\hline Stator pole arc $\left(^{\circ}\right)$ & 15 \\
\hline Rotor pole arc $\left(^{\circ}\right)$ & 16 \\
\hline Stator pole width $(\mathrm{mm})$ & 18.3 \\
\hline Rotor pole width $(\mathrm{mm})$ & 19.4 \\
\hline Stator pole length $(\mathrm{mm})$ & 35 \\
\hline Rotor pole length $(\mathrm{mm})$ & 20 \\
\hline Stator yoke thickness $(\mathrm{mm})$ & 16,5 \\
\hline Rotor yoke thickness $(\mathrm{mm})$ & 21,5 \\
\hline Shaft diameter $(\mathrm{mm})$ & 56 \\
\hline Number of turns per pole & 8 \\
\hline
\end{tabular}




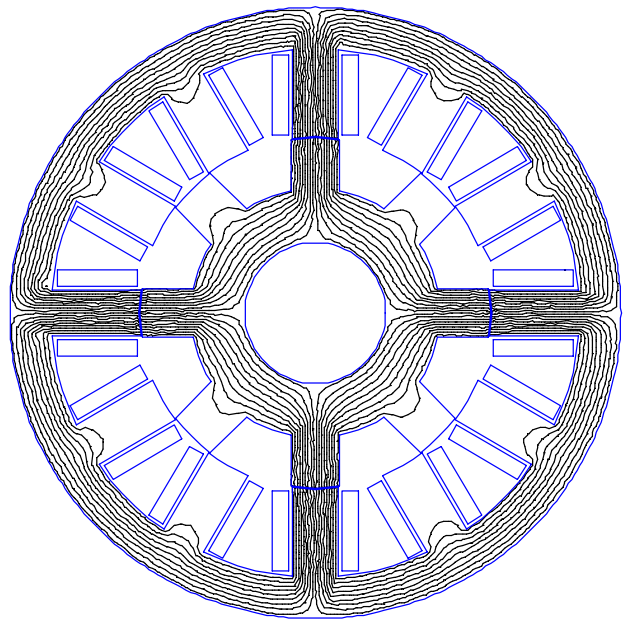

a)

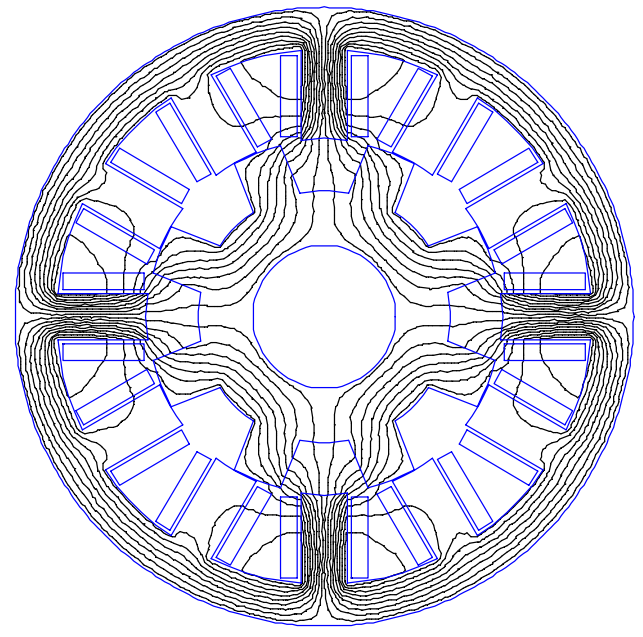

b)

Fig. 4. Finite element flux-plot for 12/8 switched reluctance motor prototype a) aligned position b) non aligned position
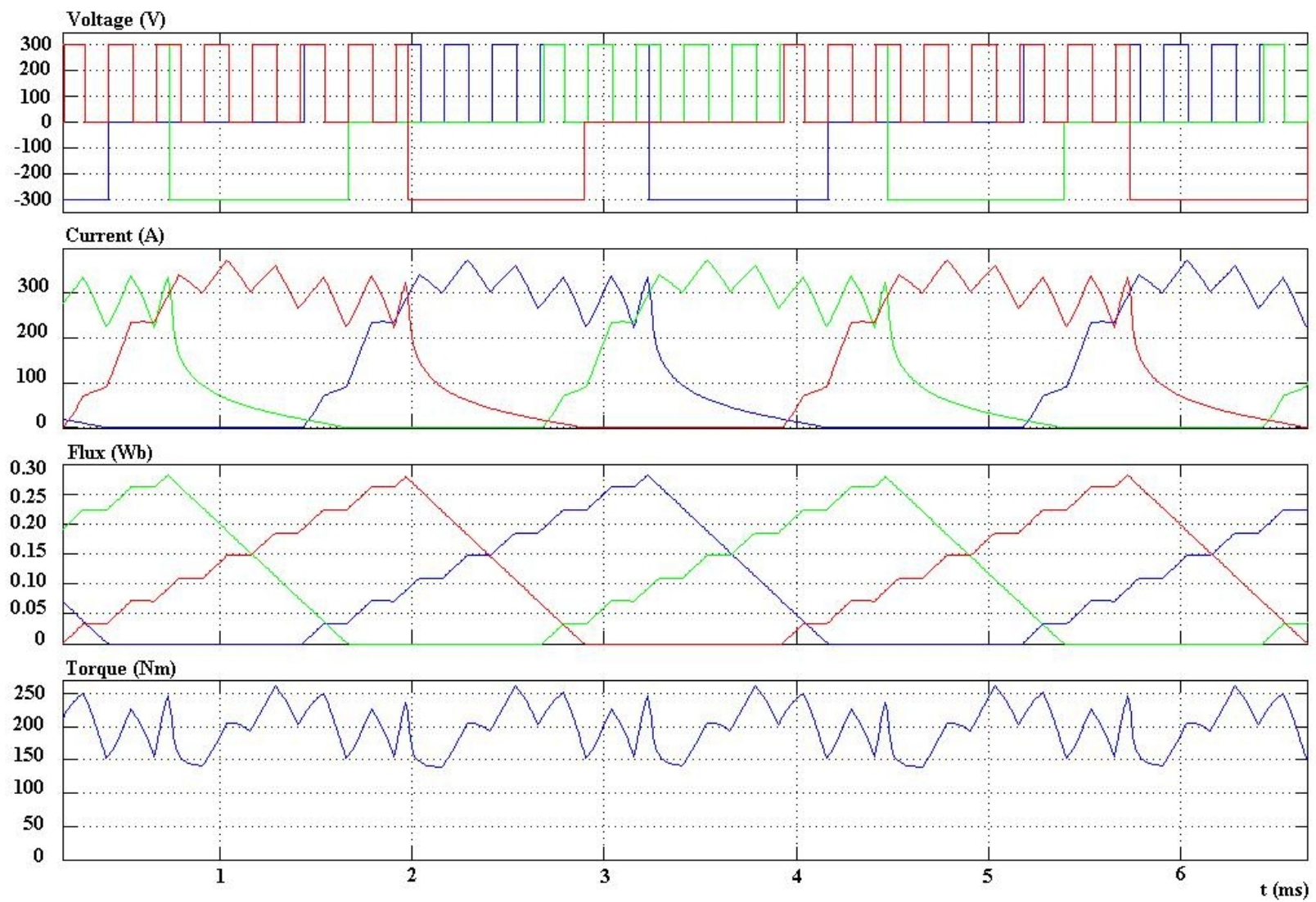

Fig. 5. Matlab/Simulink simulation. PWM control, spped $2000 \mathrm{rpm}$ 

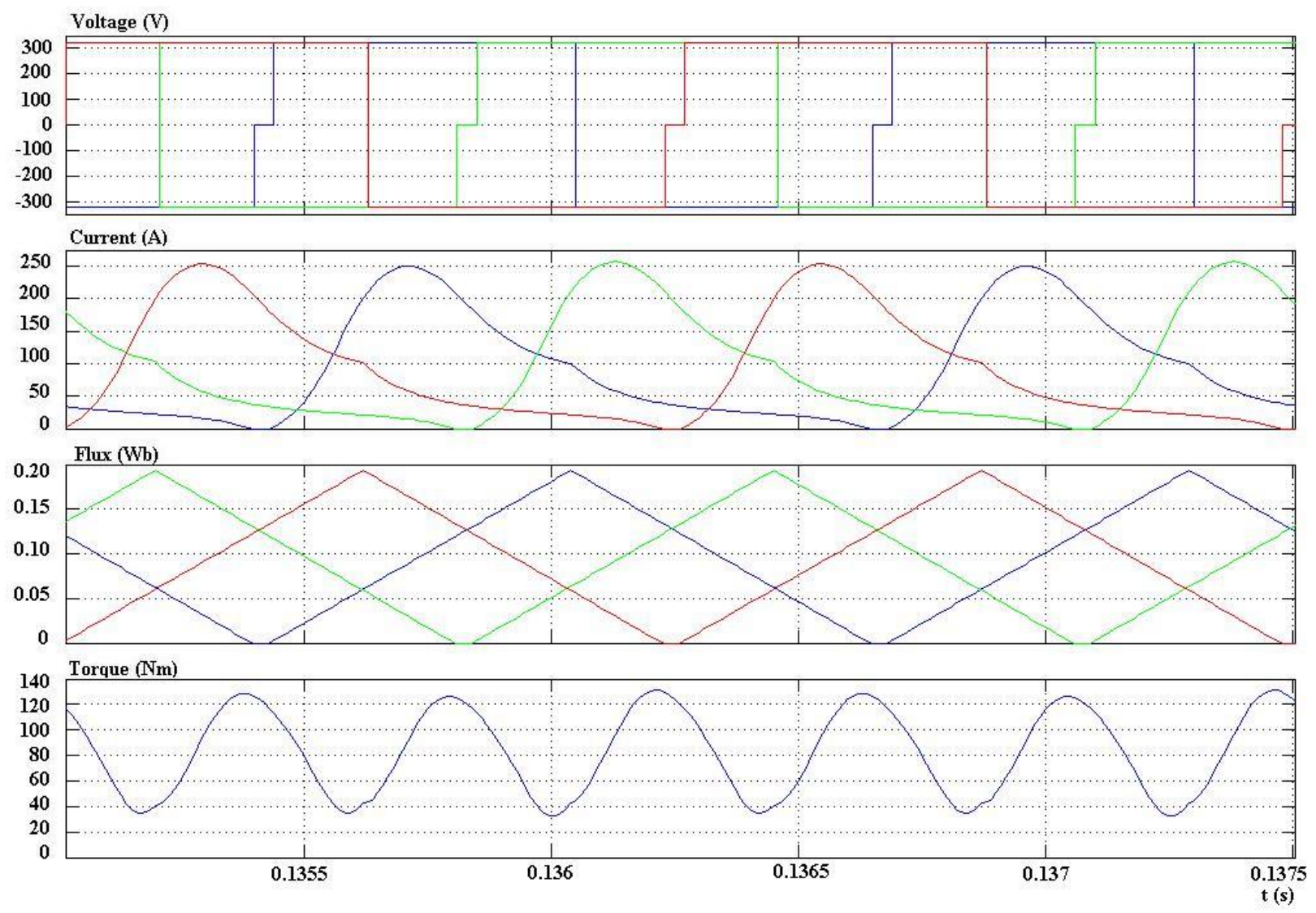

Fig. 6. Matlab/Simulink simulation. Single pulse control, speed $6000 \mathrm{rpm}$.

\section{Conclusion}

Electric vehicles are the only alternative for clean, efficient and environmentally friendly urban transport system. Switched reluctance motor drives emerge as one of the best candidates for powering the drive train of electric cars, mainly due to their high efficiency, extended power region, ruggedness and low foreseen manufacturing costs. Some switched reluctance drive design guidelines including motor sizing, power converter and control have been proposed. Finally, a 75 $\mathrm{kW}, 300 \mathrm{~V}, 12 / 8$ switched reluctance motor prototype has been designed. Simulation shows good agreement with the expected results.

\section{Acknowledgement}

The work reported here was supported by the "Ministerio de Ciencia y Tecnología" (Spain) and FEDER funds (DPI2001-2203).

\section{References}

[1] C.C. Chan and K.T. Chau. "Modern Electric Vehicle Technology". Oxford Science Publications, 2001, pp 133150.

[2] M. Eshani, K. M. Rahman, H.A. Toliyat. "Propulsion system design of electric and hybrid vehicles". IEEE Transactions on Industrial Electronics, Vol. 44, $\mathrm{N}^{\mathrm{o}}$ 1, February 1997, pp. 19-27.
[3] S.W. Moore, K.M. Rahman, M. Ehsani. "Effect on vehicle performance of extending the constant power region of electric drive motors". SAE Technical Papers Series 199901-1152, International Congress and Exposition. Detroit, Michigan, March 1-4, 1999.

[4] A. Lange, W.R. Canders, F. Laube, H. Mosebach. "Comparison of different drive systems for a $75 \mathrm{~kW}$ electrical vehicle drive". ICEM 2000, 28-30 August, Espoo, Finland, pp. 1308-1312.

[5] O. Bitsche, J. Friedrich. "Electric drive for hybrid, fuel cell and battery power vehicles". ICEM 2000, 28-30 August, Espoo, Finland, pp.1317-1321.

[6] K. Rajashekara. "Propulsion system strategies for fuel cell vehicles". SAE Technical papers series 2000-01-0368. SAE 2000 World Congress. Detroit, Michigan, March 6-9, 2000.

[7] L.Chang. "Comparison of AC drives for electric vehicle-A report on expert's opinion survey". IEEE AES Systems Magazine, August 1994, pp 7-11.

[8] P.J. Lawrenson. et al. "Variable-speed switched reluctance motors “. Proceedings IEE Vol 127 Pt B, pp 253-265, 1980.

[9] N.N. Fulton. "SR Drives for battery electric traction-a comparative assessment". IEE Coll. Motors and Drives for battery powered propulsion, 1993, pp 411-417.

[10] T. Uematsu and R.S. Wallace. "Design of $100 \mathrm{~kW}$ switched reluctance motor for electric vehicle propulsion". Proc. IEEE APEC, 1995, pp 411-415.

[11] I. Husain and M.S. Islam." Design, modeling and simulation of an electric vehicle system". SAE Technical Papers Series 1999-01-1149, International Congress and Exposition. Detroit, Michigan, March 1-4, 1999.

[12] H. Baush, A. Greif, B. Lange, R. Bautz.“A 50 kW/15000 $\mathrm{rpm}$ switched reluctance drive for an electric vehicle: Current control and performance characteristics". ICEM 2000, 28-30 August, Espoo, Finland, pp. 603-607. 
[13] H. Bausch, A. Greif, A.B.A. Nickel. "A switched reluctance and an induction machine in a drive train for an electrical vehicle under the conditions of car application". ICEM 2000, 28-30 August, Espoo, Finland, pp. 13131316.

[14] R.B.Inderka, J-P. Altendorf, L.Sjöberg, R.W. De Doncker. Design of a $75 \mathrm{~kW}$ Switched Reluctance Drive for Electric Vehicles". EVS 18 Berlin 2001.

[15] K.M. Rahman \& S.E.Schulz. "Design of high efficiency and high density switched reluctance motor for vehicle propulsion”. IAS'2001, Chicago, pp.2104-2110.
[16] K.W.E. Cheng, Y.P.B. Yeung, C.Y. Tang, X.D. Xue, D. Sutanto. "Topology analysis of switched reluctance drives for electric vehicles". Power Electronics and Variable Speed Drives, 18-19 September 2000, pp. 512-517.

[17] R. Inderka, M. Menne, R.W. De Donker. "Control of switched reluctance drives for electric vehicle applications". IEEE Transactions on Industrial Electronics, Vol. 49, No 1, February 2002, pp. 48-53.

[18] D.C. Meeker "Finite element method magnetics. User's Manual". December 1998.

[19] B.Blanqué, J.I. Perat, M. Torrent, P. Andrada "Simulation of non-linear switched reluctance motor" SAAEI'02 1820 September 2002. Alcalá de Henares, Spain. 